\title{
ANALISIS FAKTOR-FAKTOR YANG MEMENGARUHI MINAT PETANI BERUSAHATANI TEBU (STUDI KASUS: WILAYAH KERJA PABRIK GULA GEMPOLKREP, PT PERKEBUNAN NUSANTARA X)
}

\author{
ANALYSIS OF FACTORS INFLUENCING FARMER'S INTEREST \\ ON SUGARCANE FARMING \\ (CASE STUDY: GEMPOLKREP SUGAR FACTORY WORKING AREA, \\ PT PERKEBUNAN NUSANTARA X)
}

Danang Permadhi ${ }^{1)}$ dan Trikuntari Dianpratiwi ${ }^{1)}$

1) Pusat Penelitian Perkebunan Gula Indonesia, Kota Pasuruan Alamat korespondensi, Email: permadhidanang@gmail.com

\begin{abstract}
ABSTRAK
Penurunan luas lahan tebu rakyat (TR) di wilayah kerja Pabrik Gula (PG) Gempolkrep mengindikasikan minat petani dalam berusahatani tebu menurun. Oleh sebab itu, perlu dilakukan penelitian mengenai faktor-faktor yang memengaruhi minat petani dalam berusahatani tebu. Data yang digunakan adalah data primer dan sekunder. Data primer diperoleh dari 77 petani tebu dengan menggunakan kuisioner terstruktur. Analisis yang digunakan adalah analisis regresi linier berganda dengan menggunakan alat bantu software SPSS 16. Data sekunder diperoleh dari Kementerian Pertanian, PT Perkebunan Nusantara X dan PG Gempolkrep. Hasil penelitian ini menunjukkan faktor-faktor yang memengaruhi minat petani dalam berusahatani tebu adalah penguasaan lahan, pendapatan berusahatani tebu, peran petugas PG, peran Koperasi Petani Tebu Rakyat (KPTR) dan peran dinas terkait. Nilai determinasi $\mathrm{R}$ Square sebesar 0,562 menunjukkan bahwa variabel $\mathrm{X}$ (independent variable) dapat menjelaskan variabel $\mathrm{Y}$ (dependent variable) sebesar 56,2\%, sedangkan sisanya $43,8 \%$ dijelaskan oleh faktor atau variabel lain di luar model.
\end{abstract}

Kata Kunci: petani, tebu rakyat, minat, faktor, luas lahan, regresi

\section{ABSTRACT}

The decreasing of sugarcane farmer area at-Gempolkrep Sugar Factory working area indicated that farmers' interest in sugarcane cultivation has decreased. Therefore, it is necessary to do research on the factors that influence the interest of farmers in sugarcane farming. The data used were primary and secondary data. Primary data were obtained from 77 sugarcane farmers using a structured questionnaire. The data analysis used multiple linear regression analysis using the SPSS 16 software tool. Secondary data were obtained from the Ministry of Agriculture, PTPN X and Gempolkrep Sugar Factory. The results 
indicated that the factors influenced the farmer's interest in sugarcane farming were land tenure, income from sugarcane farming, the roles sugar factory officers, sugarcane farmer cooperatives (KPTR) and government. The determination value of $R$ Square of 0.562 indicates that the independent variable can explained the dependent variable by $56.2 \%$, while the remaining $43.8 \%$ was explained by factors or other variables outside the model.

Keywords: Farmer, Sugarcane Farmer, Interest, Factor, Land Area, Regression

\section{PENDAHULUAN}

Upaya pengembangan industri gula oleh pemerintah telah ditempuh dengan berbagai cara dengan tujuan tercapainya swasembada gula dan peningkatan kesejahteraan petani (Subiyono, 2014). Upaya-upaya pemerintah yang telah dilakukan untuk mendorong peningkatan produksi tebu, antara lain program kegiatan revitalisasi pabrik, pemberian kredit lunak kepada petani, subsidi harga pupuk, bantuan benih kepada petani tebu, dan sebagainya. Namun, upaya-upaya tersebut belum memberikan solusi tercapainya swasembada gula dan peningkatan kesejahteraan petani. Swasembada gula akan terwujud jika seluruh subsistem agribisnis mampu berperan secara maksimal terutama pada sisi on farm yaitu petani tebu sebagai pelaku on farm (Bustanul, 2008).

Di Indonesia petani tebu menjadi kunci keberhasilan dalam produksi gula nasional karena mayoritas tebu yang digiling oleh PGPG (pabrik gula) di Indonesia dibudidayakan oleh petani (Subiyono, 2014). Lebih dari $65,00 \%$ pasokan tebu kepada PG berasal dari petani TR (tebu rakyat). Hal ini menunjukkan pentingnya peran petani dalam proses produksi gula di Indonesia dan pencapaian swasembada gula nasional. Di sisi lain menurut Savita (2018) kebijakan pemerintah juga berpengaruh terhadap minat petani untuk menanam tebu.

PT. Perkebunan Nusantara X (PTPN X) merupakan salah satu perusahaan BUMN (Badan Usaha Milik Negara) yang bisnis utamanya adalah gula. Salah satu pabrik gula
(PG) di bawah PTPN $X$ ialah PG Gempolkrep. Kapasitas giling PG Gempolkrep sebesar \pm 7.200 TCD (Ton Cane per Day).

Kinerja tebu rakyat di PG Gempolkrep cenderung menurun apabila dilihat dari okupasi lahan tebu rakyat yang semakin menurun dalam kurun waktu tahun 20152019. Rata-rata penurunan pada 5 (lima) tahun terakhir sebesar $1,41 \%$ dengan penurunan paling tajam di tahun 2019 sebesar $8,21 \%$. Penurunan luas lahan mengindikasikan minat petani untuk berusahatani tebu juga menurun, sehingga PG Gempolkrep harus mengimbangi penurunan luas lahan tersebut dengan produktivitas tebu yang semakin meningkat. Namun, rata-rata produktivitas tebu pada 5 (lima) tahun terakhir cenderung stagnan dengan rata-rata 75 ton/ha.

Saat ini dibutuhkan pasokan tebu yang dapat memenuhi kapasitas giling dan ajeg (continue). Semakin ketatnya persaingan untuk memperoleh pasok tebu dari petani akibat dari pembangunan PG-PG baru terutama di sekitar PG Gempolkrep menyebabkan terjadinya persaingan memperoleh pasok tebu (tebu rakyat) yang semakin kuat. Lebih dari satu dekade terakhir ini PTPN X merasakan berkurangnya minat petani dalam berusahatani tebu, baik bagi petani yang sudah menanam tebu dan tidak berminat mengembangkan luas lahan tebunya, maupun petani non tebu yang belum pernah dan tidak ingin menanam tebu.

Berdasarkan permasalahan tersebut di atas, perlu dilakukan penelitian mengenai 
faktor-faktor apa saja yang memengaruhi minat petani dalam berusahatani tebu. Penelitian ini nantinya dapat dimanfaatkan untuk memberikan masukan kepada unit usaha PG Gempolkrep PTPN X untuk menumbuhkan dan meningkatkan minat petani dalam berusahatani tebu, sehingga dapat meningkatkan pasok tebu bagi PG Gempolkrep.

\section{METODE}

\section{Kerangka Pemikiran Teoritis}

Minat merupakan suatu ketertarikan individu terhadap satu obyek tertentu yang membuat individu itu sendiri merasa senang dengan obyek tersebut. Menurut Sukardi (1994) bahwa minat merupakan salah satu unsur kepribadian yang memegang peranan penting dalam mengambil keputusan masa depan. Minat mengarahkan individu terhadap suatu obyek atas dasar rasa senang atau rasa tidak senang. Perasaan senang atau tidak senang merupakan dasar suatu minat. Minat seseorang dapat diketahui dari pernyataan senang atau tidak senang terhadap suatu obyek tertentu. Crow \& Crow (1973) menjelaskan bahwa minat pada hakekatnya merupakan sebab akibat dari pengalaman. Minat berkembang sebagai hasil dari pada suatu kegiatan dan akan menjadi sebab akan dipakai lagi dalam kegiatan yang sama. Minat timbul bila ada pehatian dengan kata lain minat merupakan sebab dan akibat dari perhatian. Menurut Wetherington (1999) minat adalah perhatian seseorang terhadap sesuatu yang dipelajari sehingga ia mempunyai sikap yang positif dan merasa senang terhadap hal tersebut, sebaliknya perasaan tidak senang akan menghambat sikap positif terhadap sesuatu. Minat timbul karena adanya faktor internal dan eksternal yang menentukan seseorang menaruh minat.
Adapun faktor-faktor dalam diri seseorang yang memengaruhi minat seseorang seperti sikap, kepribadian, pengalaman, pendidikan, harapan dan lainlainnya. Sedangkan, faktor-faktor dari luar dapat ditimbulkan oleh berbagai faktor/sumber seperti pengaruh pimpinan, teman/kolega ataupun faktor-faktor lain yang sangat komplek (Baga dan Setiadi, 2008). Faktor lain yang memengaruhi minat dari dalam diri ataupun lingkungan masyarakat menurut Crow \& Crow dalam Susilowati (2010) adalah: (1) Faktor dorongan internal, merupakan faktor yang mendorong fisik, motif dan pertahanan diri dari rasa takut, lapar sakit dan sebagainya. Sebagai contoh jika individu merasa lapar akan menimbulkan minat untuk mencari makanan; (2) Faktor motif sosial, merupakan faktor yang menimbulkan minat melakukan aktivitas untuk memenuhi kebutuhan sosial; (3) Faktor perasaan atau emosional, yaitu faktor yang dapat memacu perasaan minat individu karena menghasilkan perasaan senang yang memacu/memperkuat minat yang sudah ada. Terdapat 3 (tiga) karakteristik minat menurut Crow \& Crow (1973) dan Hurlock (1994), yaitu: (1) Minat memiliki dampak sikap positif yang muncul dari suatu obyek; (2) Minat merupakan suatu yang menyenangkan yang muncul dari suatu obyek; (3) Minat mengandung unsur apresiasi atau penghargaan, sehingga berdampak pada rasa ingin dan gairah untuk memperoleh sesuatu yang diinginkan.

Sehubungan dengan penjelasan para ahli mengenai hakikat minat seseorang, minat petani untuk menanam tebu juga dipengaruhi oleh ketertarikan/rasa senang, perhatian dan kebutuhan menanam tebu. Minat petani tebu untuk tetap atau meningkatkan produksi tebunya dapat diketahui dari perkembangan luas lahan, produksi ataupun produktivitas tanaman tebu yang dibudidayakan. 


\section{Hipotesis Penelitian}

Hipotesis dalam penelitian ini terdiri dari hipotesis utama dan hipotesis kerja. Hipotesis utama pada penelitian ini adalah "Faktor internal dan eksternal petani yang berhubungan dengan minat petani dalam berusahatani tebu". Hipotesis kerja adalah pengujian hipotesis yang lebih mengarah pada variabel-variabel yang akan diuji pada penelitian ini, yaitu adanya pengaruh faktor internal (umur, pendidikan formal, pengalaman berusahatani tebu, tanggungan keluarga, penguasaan lahan, produktivitas tebu, pendapatan usahatani tebu) dan faktor eksternal (peran petugas PG, Peran APTR, Peran KPTR dan Peran Dinas Terkait) terhadap minat petani berusahatani tebu, khususnya di wilayah kerja PG Gempolkreb.

\section{Kerangka Pemikiran Operasional}

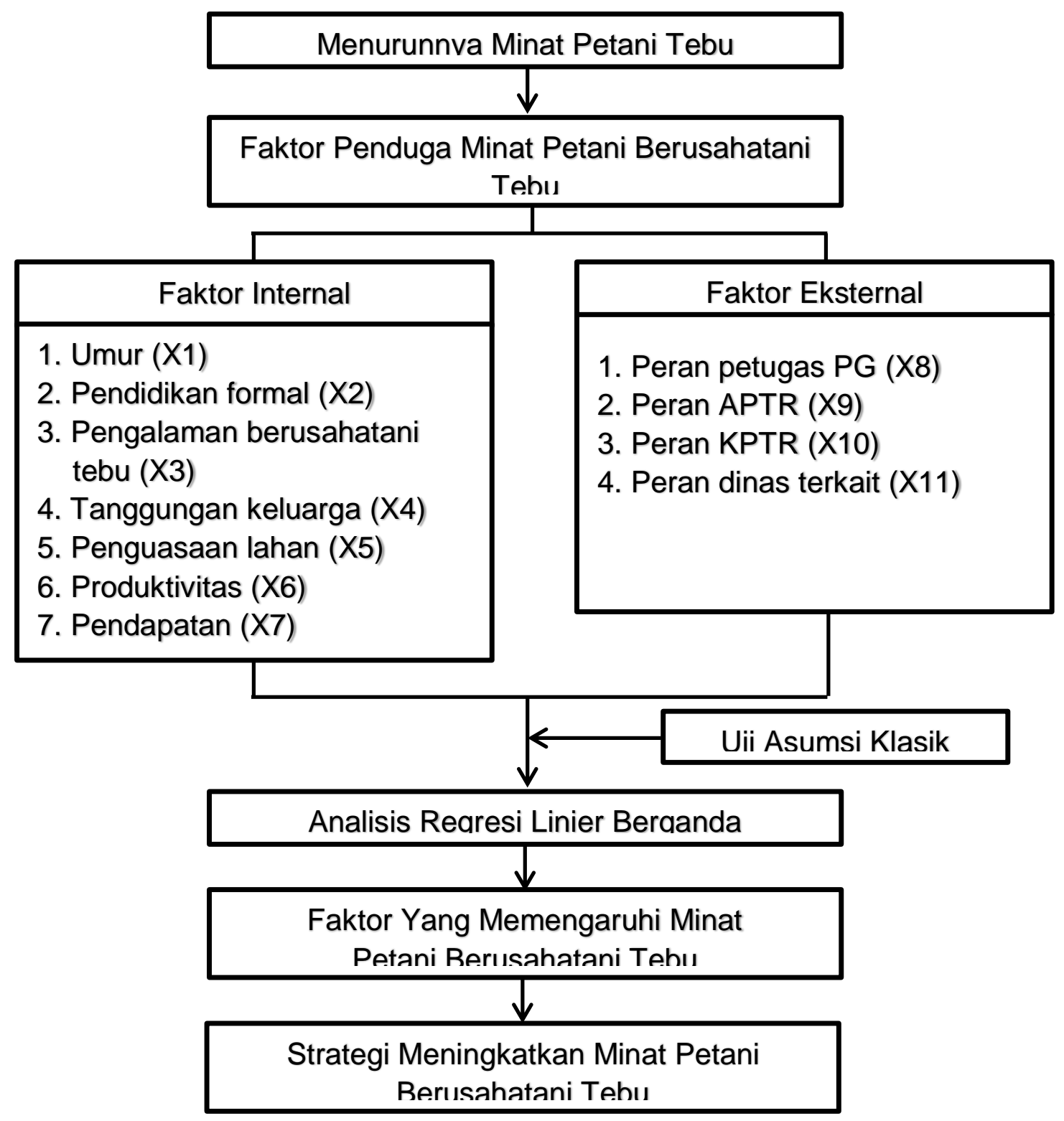

Gambar 1. Kerangka Pemikiran Operasional Minat Berusahatani Tebu

Figure 1. Interested Operational Frameowrk of Sugarcane Farming 


\section{Lokasi Dan Waktu Penelitian}

Lokasi penelitian ini berada di 3 (tiga) wilayah kerja PG Gempolkrep (PTPN X), yaitu di Kabupaten Mojokerto, Lamongan dan Gresik. Waktu penelitian dilakukan selama 3 bulan (Mei-Juli) tahun 2019 mulai dari persiapan/perizinan, pengambilan dan rekapitulasi/pengolahan data serta analisa data. Penentuan daerah penelitian dilakukan secara purposive sampling berdasarkan sentra produksi tebu terluas.

\section{Jenis Dan Sumber Data}

Data yang digunakan pada penelitian ini adalah data primer dan data sekunder. Data primer diperoleh dari wawancara mendalam (depth interview) yang terstruktur serta pengamatan langsung pada objek penelitian yaitu para petani tebu rakyat di wilayah kerja PG Gempolkrep PTPN X sejumlah 77 responden. Sedangkan, sumber data sekunder diperoleh dari Badan Pusat Statistik (BPS) Indonesia, Direktorat Jendral Perkebunan (Kementerian Pertanian), PTPN X dan PG Gempolkrep. Metode yang digunakan adalah non probability sampling (sampel tidak acak) dengan teknik sampel jenuh dikarenakan jumlah anggota atau unsur di dalam populasi yang relatif kecil, sehingga semua anggota di dalam populasi akan dijadikan sebagai sampel (Ardial. 2014).

\section{Metode Pengolahan Dan Analisis Data}

\section{a. Tingkat Minat}

Alat analisis yang digunakan untuk melihat minat petani berusahatani tebu menggunakan kuisioner terstruktur. Indikator yang digunakan untuk melihat tingkat minat petani yaitu; (1) Persepsi petani atas pendapatan usahatani tebu; (2) Rencana perluasan okupasi lahan tebu; (3) Pendapat jika usahatani tebu tetap merugikan; serta (4) Pendapat jika usahatani tebu menguntungkan.
Indikator tersebut disesuaikan dan diperoleh dari beberapa penelitian terdahulu.

Data dianalisis secara deskriptif kuantitatif yang bertujuan untuk mengetahui tingkat minat petani dalam berusahatani tebu, sehingga dapat memberikan rekomendasi untuk meningkatkan minat petani dalam berusahatani tebu. Selanjutnya, jawaban dari petani diberikan bobot dan dijumlahkan untuk dijadikan skor penilaian terhadap veriabel yang akan diteliti.

\section{b. Faktor internal dan eksternal}

Faktor internal dan eksternal merupakan faktor-faktor yang diduga mempunyai pengaruh (variabel $\mathrm{X}$ ) dengan minat petani berusahatani tebu (variabel $Y$ ). Dalam penelitian ini, variabel yang diukur terdiri dari; (1) Umur (X1), yaitu usia petani saat dilakukan pengambilan data yang diukur dalam satuan tahun; (2) Pendidikan formal (X2), yaitu tingkat pendidikan di sekolah petani yang diperoleh secara sistematis, teratur, berjenjang/bertingkat dan mengikuti aturan/syarat-syarat yang jelas; Pengalaman berusahatani (X3), yaitu lamanya budidaya petani menjalankan usahatani tebu, diukur dalam satuan tahun; (4) Tanggungan keluarga (X4), yaitu jumlah anggota keluarga yang menjadi tanggungan rumah tangga; (5) Penguasaan lahan (X5), yaitu luas lahan tebu yang diusahakan, diukur dalam satuah hektar; (6) Produktivitas tebu (X6), yaitu jumlah bobot tebu per hektar yang dapat diperoleh petani, diukur dalam satuan ton per hektar; (7) Pendapatan (X7), yaitu besaran sisa hasil usahatani tebu, diukur dalam satuan rupiah per hektar; (8) Peran petugas PG (X8), yaitu dilihat dari jumlah bimbingan/penyuluhan dari petugas $\mathrm{PG}$, keterlibatan petani dalam penyusunan rencana usaha (periode giling), peran petugas PG dalam memfasilitasi jaminan kredit usahatani tebu dan peran petugas PG dalam mendistribusikan SPTA kepada petani tebu; 
(9) Peran APTR (X9), yaitu dilihat dari jumlah bimbingan/penyuluhan dari APTR; (10) Peran KPTR yaitu dilihat dari jumlah bimbingan/penyuluhan dari KPTR dan kemudahan memperoleh fasilitas pinjaman kredit usaha; dan (11) Peran dinas terkait, yaitu dilihat dari jumlah bimbingan/ penyuluhan dari dinas terkait.

\section{c. Analisis Data}

Analisis data yang digunakan pada penelitian ini adalah regresi linier berganda. Model ini digunakan untuk mengetahui faktor-faktor penduga yang memengaruhi minat petani berusahatani tebu di wilayah kerja PG Gempolkrep. Pengujian yang dilakukan terdiri dari:

1) Uji Asumsi Klasik

Sebelum model regresi digunakan, maka terlebih dahulu dilakukan pengujian asumsi klasik, yaitu terdiri dari: (1) Uji multikolinieritas; (2) Uji heteroskedastisitas; dan (3) Uji normalitas.

\section{2) Uji Regresi Linier Berganda}

Uji Regresi linier berganda pada penelitian ini terdiri dari Uji Koefisien Determinasi $\mathrm{R}$ Square, Uji-F dan Uji-t. Koefisien determinasi pada intinya mengukur seberapa besar persentase variasi variabel bebas dapat menjelaskan variabel terikatnya. Nilai koefisien determinasi adalah antara nol dan satu. Nilai $R^{2}$ yang kecil berarti kemampuan variabel-variabel bebas dalam menjelaskan variasi variabel terikat yang sangat terbatas. Nilai yang mendekati satu berarti variabel-variabel bebas memberikan hampir semua informasi yang dibutuhkan untuk memprediksi variasi variabel terikat.

Uji $\mathrm{F}$ bertujuan untuk mengetahui pengaruh variabel $\mathrm{X}$ terhadap variabel $\mathrm{Y}$ secara simultan. Kriteria pengujiannya adalah apabila nilai $\mathrm{F}$ hitung $>$ Ftabel maka variabel $\mathrm{X}$ secara bersama-sama (simultan) mempunyai pengaruh terhadap variabel $\mathrm{Y}$ begitupun sebaliknya. Sedangkan pada Uji t bertujuan untuk mengetahui pengaruh variabel $X$ terhadap Y secara parsial. Kriteria pengujiannya adalah apabila nilai $t$ hitung $>t$ tabel maka secara parsial (masing-masing variabel $\mathrm{X}$ ) mempunyai pengaruh terhadap variabel $\mathrm{Y}$ begitupun sebaliknya.

Berikut adalah model persamaan regresi yang akan diuji:

$$
\begin{aligned}
Y=\beta_{1}+\beta_{2} X_{1} & +\beta_{3} X_{2}+\beta_{4} X_{3}+\beta_{5} X_{4} \\
& +\beta_{6} X_{5}+\beta_{7} X_{6}+\beta_{8} X_{7} \\
& +\beta_{9} X_{8}+\beta_{10} X_{9}+\beta_{11} X_{10} \\
& +\beta_{12} X_{11}+\varepsilon
\end{aligned}
$$

Keterangan:

$\begin{array}{ll}\mathrm{Y} & : \text { Minat petani tebu } \\ \beta_{1} & : \text { Konstanta } \\ \beta_{2}-\beta_{12} & : \text { Koefisien } \\ X_{1} & : \text { Umur } \\ X_{2} & : \text { Pendidikan formal } \\ X_{3} & : \text { Pengalaman usahatani tebu } \\ X_{4} & : \text { Tanggungan keluarga } \\ X_{5} & \text { : Penguasaan lahan } \\ X_{6} & \text { : Produktivitas tebu } \\ X_{7} & : \text { Pendapatan usahatani tebu } \\ X_{8} & : \text { Peran petugas PG } \\ X_{9} & : \text { Peran APTR } \\ X_{10} & : \text { Peran KPTR } \\ X_{11} & : \text { Peran dinas terkait } \\ \varepsilon & : \text { Error term }\end{array}$

\section{HASIL DAN PEMBAHASAN}

\section{Hasil Analisis Regresi Linier Berganda}

Hasil pengujian analisis regresi linier berganda terdiri dari hasil Uji determinasi RSquare, Uji-F dan Uji-t. Pengolahan data menggunakan alat statistik SPSS 16. Hasil analisis regresi linier berganda disajikan dalam Tabel 1. 
Tabel 1. Hasil Analisis Uji Parsial (Uji-t)

Table 1. Partial Test (t-test) analysis result

\begin{tabular}{|c|c|c|}
\hline $\begin{array}{l}\text { Variabel } \\
\text { Variable }\end{array}$ & $\begin{array}{l}\text { Koefisien } \\
\text { Coeficient }\end{array}$ & $\begin{array}{c}T_{\text {Hitung }} \\
T_{\text {value }}\end{array}$ \\
\hline Konstanta & 3,291 & $5,008^{*}$ \\
\hline Constanta & & \\
\hline Umur petani (X1) & $(-0,015)$ & $(-2,547)$ \\
\hline Farmer's age & & \\
\hline Pendidikan Formal (X2) & $(-0,080)$ & $(-1,672)$ \\
\hline Formal education & & \\
\hline Pengalaman Berusahatani (X3) & $(-0,010)$ & $(-1,054)$ \\
\hline Sugarcane farming experiences & & \\
\hline Tanggungan Keluarga (X4) & $(-0,045)$ & $(-0,989)$ \\
\hline Family dependant & & \\
\hline Penguasaan Lahan (X5) & 0,007 & $1,306^{*}$ \\
\hline Land tenure & & \\
\hline $\begin{array}{l}\text { Produktivitas Tebu (X6) } \\
\text { Sugarcane productivity }\end{array}$ & $(-0,002)$ & $(-0,590)$ \\
\hline $\begin{array}{l}\text { Pendapatan Usahatani tebu (X7) } \\
\text { Sugarcane farming income }\end{array}$ & 0,005 & $1,108^{*}$ \\
\hline $\begin{array}{l}\text { Peran Petugas PG (X8) } \\
\text { Role of Sugar factory staffs }\end{array}$ & 0,075 & $1,079 *$ \\
\hline Peran APTR (X9) & $(-0,106)$ & $(-1,562)$ \\
\hline $\begin{array}{l}\text { Role of Farmer association } \\
\text { Peran KPTR (X10) }\end{array}$ & 0,511 & $7,612 *$ \\
\hline $\begin{array}{l}\text { Role of Farmer cooperation } \\
\text { Peran Dinas Terkait (X11) } \\
\text { Role of related government services }\end{array}$ & 0,033 & $0,862 *$ \\
\hline R Square $=0,562 ; F_{\text {Hitutng }}=757,2$ & & \\
\hline
\end{tabular}

Sumber: Data primer, diolah

Keterangan:

*) Nyata pada taraf kepercayaan $75 \%$

Sehingga, model persamaan regresi yang diperoleh adalah sebagai berikut ini:

$$
\begin{aligned}
Y= & 3,291+(-0,015) X_{1}+(-0,080) X_{2}+(-0,010) X_{3}+(-0,045) X_{4} \\
& +(0,007) X_{5}+(-0,002) X_{6}+0,005 X_{7}+(0,075) X_{8}+(-0,106) X_{9} \\
& +0,511 X_{10}+0,033 X_{11}
\end{aligned}
$$

Hasil Uji determinasi R-Square penelitian ini diperoleh niai R-Square sebesar 0,562 menunjukkan bahwa variabel $\mathrm{X}$ dapat menjelaskan variabel $\mathrm{Y}$ sebesar $56,2 \%$, sedangkan sisanya $43,8 \%$ dijelaskan oleh faktor/variabel lain diluar model. Hasil uji $\mathrm{F}$ penelitian ini diperoleh $\mathrm{F}$ Hitung sebesar 757,2 dengan nilai signifikansi 0,00 dan nilai F Tabel sebesar 1,29 dengan tingkat signifikansi $75 \% \quad(\alpha=0,25)$. Sesuai dengan kriteria Uji $F$ (F Hitung $>F$ Tabel), maka variabel $\mathrm{X}$ secara bersama-sama (simultan) 
mempunyai pengaruh terhadap variabel $\mathrm{Y}$ (minat petani berusahatani tebu). Sedangkan pada hasil Uji-t secara parsial dari 11 (sebelas) variabel yang diuji, terdapat 5 (lima) variabel yang berpengaruh secara nyata terhadap minat petani berusahatani tebu. Hal ini dapat diketahui dari nilai thitung $>$ t-tabel. Nilai t-tabel diketahui sebesar 0,678 dengan tingkat signifikansi $75 \%$ $(\alpha=0,25)$. Variabel yang berpengaruh secara nyata terhadap minat petani berusahatani tebu adalah penguasaan lahan (X5), pendapatan usahatani tebu (X7), peran petugas PG (X8), peran KPTR (X10), peran dinas terkait (X11).

Pada nilai koefisien regresi merupakan nilai elastisitas masing-masing variabel. Pada variabel yang berpengaruh secara nyata terhadap minat petani berusahatani tebu di atas meliputi: (1) Penguasaan lahan (X5), mempunyai pengaruh positif terhadap minat petani berusahatani tebu dengan nilai koefisien 0,007 , artinya setiap penambahan jumlah penguasaan (okupasi) lahan tebu satu poin maka menunjukkan peningkatan minat petani sebesar 0,007 dengan asumsi bahwa variabel lainnya tetap/konstan;

Pendapatan usahatani tebu (X7), mempunyai pengaruh positif terhadap minat petani berusahatani tebu dengan nilai koefisien 0,005 , artinya setiap penambahan jumlah pendapatan usahatani tebu satu poin maka menunjukkan peningkatan minat petani sebesar 0,005 dengan asumsi bahwa variabel lainnya tetap/konstan; (3) Peran petugas PG (X8), mempunyai pengaruh positif terhadap minat petani berusahatani tebu dengan nilai koefisien $0,075, \quad$ artinya setiap penambahan/peningkatan peran petugas PG satu poin maka menunjukkan peningkatan minat petani sebesar 0,075 dengan asumsi bahwa variabel lainnya tetap/konstan; (4) Peran KPTR (X10), mempunyai pengaruh positif terhadap minat petani berusahatani tebu dengan nilai koefisien 0,511, artinya setiap penambahan/peningkatan peran KPTR satu poin maka menunjukkan peningkatan minat petani sebesar 0,511 dengan asumsi bahwa variabel lainnya tetap/konstan; (5) Peran dinas terkait (X11), mempunyai pengaruh positif terhadap minat petani berusahatani tebu dengan nilai koefisien 0,033, artinya setiap penambahan/ peningkatan peran dinas terkait satu poin maka menunjukkan peningkatan minat petani sebesar 0,033 dengan asumsi bahwa variabel lainnya tetap/konstan.

\section{Rekomendasi untuk Meningkatkan Minat Petani dalam Berusahatani Tebu}

\section{a. Rekomendasi untuk Faktor Internal}

Kepemilikan luas lahan tebu petani yang tidak besar dapat membuat petani memandang usahatani yang dilakukan hanyalah sampingan. Tentu hal ini harus dihindari agar petani tebu lebih konsisten dan terus berusaha untuk menambah okupasi lahan yang diusahakan melalui skema sewa lahan, bagi hasil/keuntungan ataupun bekerjasama dengan lahan-lahan milik Perhutani di wilayah KPH Lamongan, Mojokerto dan Bojonegoro. Okupasi luas lahan petani tebu menjadi indikator minat petani berusahatani tebu, yaitu semakin bertambah luas lahan tebu, maka semakin tinggi minat petani berusahatani tebu begitupun sebaliknya (Subiyono, 2014).

Harga dasar gula ditetapkan pemerintah bersama lembaga-lembaga terkait dengan memperhatikan HPP (harga pokok produksi) bagi tebu yang dihasilkan oleh petani TR (tebu rakyat). Besaran pendapatan yang diperoleh dari usahatani tebu juga dapat mendorong petani berminat menanam tebu. Pendapatan usahatani tebu dilihat dari seberapa banyak gula yang dihasilkan dari tebu yang diserahkan PG. Selain itu, petani juga dapat memperoleh pendapatan dari tetes. Permasalahannya adalah rendahnya rendemen (\% kadar gula di dalam batang tebu) perlu diatasi dengan adanya 
penyuluhan/pendampingan yang efektif dan efisien agar petani tebu lebih berusaha untuk memperbaiki kualitas budidaya tebunya. Selain itu, PG juga perlu memperbaiki/ meningkatkan efisiensinya dengan cara menekan jam berhenti giling dan potensi kehilangan gula. Oleh sebab itu, untuk memperoleh pendapatan yang tinggi bagi petani TR dapat dilakukan dengan cara memaksimalkan pendapatan dan pengendalian biaya. Memaksimalkan pendapatan dapat dilakukan dengan cara: (1) Menekan biaya produksi dan biaya operasional serendah-rendahnya; (2) Menjaga kualitas tebu; (3) Menentukan dan mempertahankan harga sesuai rencana pendapatan yang akan dicapai; (4) Manajemen TMA (tebang, muat dan angkut) yang efektif dan efisien; serta (5) Meningkatkan volume produksi semaksimal mungkin. terdapat 3 (tiga) strategi dalam pengendalian biaya, yaitu dengan cara mengurangi biaya produksi, mengurangi frekuensi pekerjaan dan menggabungkan beberapa pekerjaan kebun.

\section{b. Rekomendasi untuk Faktor Eksternal}

Peran petugas PG tidak dapat lepas dari kemitraan yang saling membutuhkan antara petani tebu rakyat dengan sub sistem hilir yaitu PG. Oleh sebab itu, kemitraan menjadi alternatif pilihan bagi petani tebu dan PG Gempolkrep karena sebagian besar pasok tebu dari petani TR. Petugas PG dapat memberikan pendampingan/penyuluhan dan fasilitas penunjang lainnya untuk memperoleh bahan baku tebu yang berkualitas. Kegiatan program penyuluhan ataupun fasilitas yang dapat diberikan berupa: (1) Penyediaan/pengawalan varietas benih tebu unggul yang dibudidayakan petani; (2) Penyediaan tenaga ahli dan atau peningkatkan intensitas penyuluhan/pelatihan kepada petani tebu mengenai evaluasi teknis budidaya eksisting dan informasi teknologi budidaya tebu terbaru yang lebih efektif dan efisien; (3) Membantu petani dalam pengelolaan dan pelaksanaan pinjaman modal usaha (kredit); serta (4) Membantu petani dalam pemenuhan/ketersediaan saprodi.

Permodalan petani adalah salah satu faktor yang mendukung keberhasilan pengembangan usahatani tebu di wilayah kerja PG Gempolkrep. Upaya yang dapat dilakukan pemerintah melalui KPTR di wilayah kerja PG Gempolkrep dengan cara mengembangkan skema kredit dengan suku bunga yang lebih rendah. Kebutuhan permodalan petani tebu dengan suku bunga yang rendah diharapkan petani dapat mengaplikasikan teknologi rekomendasi budidaya yang dianjurkan. Ariningsih (2015) menyimpulkan peran KPTR dalam agribisnis tebu adalah: (1) Memberdayakan petani melalui kegiatan-kegiatan penyuluhan budidaya tanaman tebu bagi petani/anggota; (2) Aktif membantu petani/anggota untuk meningkatkan kualitas tanaman tebu; (3) Memfasilitasi petani/anggota dalam pelatihan/penyuluhan, permodalan, pengadaan saprodi, alsintan dan hal-hal lainnya yang diperlukan untuk menunjang kegiatan budidaya tebu serta (4) sebagai jembatan antarpetani, PG, APTR maupun pemerintah.

Peran dinas terkait sangat erat hubungannya dengan bantuan pemerintah dalam mendorong peningkatan produktivitas tebu petani. Selain itu, dinas terkait melalui BPP (Balai Penyuluh Pertanian) yang berada di setiap kecamatan dapat membantu PG mendorong program pencapaian swasembada gula yang sudah dicanangkan sejak tahun 2010. Peran dinas terkait yang dapat dilakukan adalah: (1) Rekomendasi varietas tebu unggul; (2) Penyediaan saprodi dan alsintan; serta (3) Aktif bersama PG membantu petani untuk meningkatkan kualitas tanaman tebu yang dibudidayakan. 


\section{KESIMPULAN}

Mengacu kepada data, fakta serta pembahasan pada bagian sebelumnya, maka dapat ditarik kesimpulan sebagai berikut: (1) Hasil Uji determinasi R Square penelitian ini diperoleh niai $\mathrm{R}$ Square sebesar 0,562 menunjukkan bahwa variabel $\mathrm{X}$ dapat menjelaskan variabel $\mathrm{Y}$ sebesar 56,2\%, sedangkan sisanya 43,8\% dijelaskan oleh faktor atau variabel lain di luar model; (2) Hasil Uji $F$ menunjukkan bahwa nilai $F$ Hitung $(757,2)>F$ Tabel $(1,29)$, maka variabel $\mathrm{X}$ secara bersama-sama (simultan) mempunyai pengaruh terhadap variabel $\mathrm{Y}$ (minat petani berusahatani tebu); (3) Hasil Uji $\mathrm{t}$ menunjukkan bahwa nilai $\mathrm{t}$ hitung $>\mathrm{t}$ tabel $(0,678)$, maka variabel $\mathrm{X}$ secara parsial mempunyai pengaruh terhadap variabel $\mathrm{Y}$ (minat petani berusahatani tebu) adalah penguasaan lahan (X5), pendapatan usahatani tebu (X7), peran petugas PG (X8), peran KPTR (X10) dan peran dinas terkait (X11). Faktor internal yang memengaruhi minat berusahatani tebu adalah penguasaan lahan dan pendapatan usahatani tebu, sedangkan faktor eksternal yang memengaruhi minat berusahatani tebu adalah peran petugas $\mathrm{PG}$, peran KPTR dan peran dinas terkait.

Oleh sebab itu, berdasarkan hasil kajian ini, diperlukan kebijakan pemerintah tentang pertebuan khususnya untuk petani TR berlahan sempit ( $<2$ ha) sehubungan dengan semakin menurunnya luas lahan dan pasok bahan baku tebu setiap tahunnya. Kebijakan tersebut misalnya regrouping lahan, permodalan dan bantuan sarana produksi. selian itu, harga dasar (provenue) yang ditetapkan pemerintah dapat diperhitungkan secara matang dengan memperhatikan HPP (harga pokok produksi) rata-rata petani. Peran APTR dapat lebih mendorong minat petani untuk menanam atau memperluas okupasi lahan tebu. Selain itu, dapat lebih aktif memberikan pelatihan/penyuluhan atas teknologi budidaya tebu terbaru dan turut serta mengawasi dan memfasilitasi ketersediaan/bantuan saprodi. Transparansi dari berbagai pihak dalam pertebuan untuk meminimalisir kecurigaan ataupun ketidakpercayaan yang timbul dengan penentuan kualitas tebu secara individual yang adil bagi petani tebu rakyat. Untuk itu diperlukan sistem menajemen pengawasan yang independen dalam penentuan kualitas tebu rakyat (rendemen).

\section{DAFTAR PUSTAKA}

Ardial. (2014) Paradigma dan Model Penelitian Komunikasi. Jakarta: PT Bumi Aksara.

Ariningsih. E. 2016. Peran Koperasi Tebu Dalam Upaya Pemberdayaan Petani Tebu Di Jawa Timur: 325-324, Litbang pertanian, diakses 07 Februari 2021. https://pse.litbang.pertanian.go.id/ind/p dffiles/prosiding_2016/3_6.pdf

Baga M. L. dan Setiadi R. (2008). Analisis Faktor-Faktor yang Berhubungan dengan Motivasi Petani dalam Berusahatani Tebu. Jurnal Agribisnis dan Ekonomi Pertanian. 2 (2): 21-38

Bustanul, A. (2008). Ekonomi Swasembada Gula Indonesia. Economic Review. 211: 1-12. Diakses 08 Februari 2021. https://www.researchgate.net

Crow and Crow. (1973). An Outline Of Psikology (Terjemahan Z. Kazjian). Surabaya. PT Bina Ilmu

Hurlock, E. B. (1994) Psikologi Perkembangan (Suatu Pendekatan Sepanjang Rentang Kehidupan). Jakarta. Erlangga.

Sukardi, D. K. (1994) Bimbingan Karir di Sekolah-Sekolah. Jakarta. Ghalia Indonesia

Savita. (2018) Kemitraan Antara Petani Tebu dengan Pabrik Gula (Studi Kasus Pada Petani Tebi di Ds. Mangli Wetan, Kec. 
Tapen, Kab. Bondowoso. Thesis. Susilowati, E. T. (2010) Hubungan Minat Universitas Airlangga. Diakses 07 Februari 2021. http://repository.unair.ac.id/70239/1708 $\underline{2}$

Subiyono. (2014) Sumbangan Pemikiran Menggapai Kejayaan Industri Gula Nasional, PT Perkebunan Nusantara X (Persero) Surabaya.

Menonton Tayangan Film Kartun Laga di Televisi dengan Agresivitas Siswa SDN Ngimbang Palang Tuban. Malang: Skripsi Universitas Islam Negeri Maulana Malik Ibrahim Malang (Tidak Diterbitkan).

Wetherington, H.C. 1999. Psikologi Pendidikan. Jakarta. Aksara Baru 